\title{
Pengembangan Tanaman Sereh Wangi untuk Bioreklamasi Lahan dan Pemberdayaan Ekonomi Masyarakat di Muaro Jambi
}

\section{(Development of Citronella for Land Bioreclamation and Community Economic Empowerment in Muaro Jambi)}

\author{
Mursalin Mursalin ${ }^{*}$, Eva Achmad ${ }^{2}$, Ardi Novra ${ }^{3}$ \\ 1 Program Studi Teknik Pertanian, Fakultas Pertanian, Universitas Jambi Jl. Raya Jambi-Muara Bulian Km.15 Mendalo \\ Indah, Muaro Jambi, Jambi 36361. \\ 2 Program Studi Kehutanan, Fakultas Pertanian, Universitas Jambi Jl. Raya Jambi-Muara Bulian Km.15 Mendalo Indah, \\ Muaro Jambi, Jambi 36361. \\ 3 Program Studi Peternakan, Fakultas Peternakan, Universitas Jambi Jl. Raya Jambi-Muara Bulian Km.15 Mendalo Indah, \\ Muaro Jambi, Jambi 36361. \\ *Penulis Korespondensi: mursalin@unja.ac.id \\ Diterima Oktober 2019/Disetujui Agustus 2020
}

\begin{abstract}
ABSTRAK
Banyak lahan terdegradasi di Desa Kebon IX, Kecamatan Sungai Gelam, Kabupaten Muaro Jambi akibat kegiatan industri batu bata, perdagangan tanah timbunan, dan atau kegiatan penambangan batubara. Tujuan kegiatan pengabdian ini adalah mendorong aksi kolektif masyarakat Desa Kebun IX untuk mengaplikasikan teknologi budi daya dan pengolahan sereh wangi dalam rangka merehabilitasi lahan sekaligus mengembangkan usaha ekonomi produktif (UEP). Diharapkan UEP yang terbina dapat menjadi mata pencarian pengganti usaha lama yang tidak ramah lingkungan (usaha tanah timbunan, industri batubata, dan penambangan batubara). Metode kegiatan adalah kombinasi antara pendekatan Participatory Rural Appraisal (PRA) dan model aksi kolektif (collective action model) dalam strategi promosi dan adopsi teknologi. Melalui kegiatan penyuluhan, pelatihan, demplot, dan pendampingan, empat jenis UEP yang saling terintegrasi, meliputi kegiatan budi daya, pengolahan, dan pemanfaatan produk samping tanaman sereh wangi, berhasil dikembangkan di Desa Kebon IX. Budi daya sereh wangi selain dapat mereklamasi fungsi lahan juga dapat menghasilkan income bagi masyarakat. Sereh wangi berumur 6-8 bulan menghasilkan daun dengan harga Rp 500/kg dan setelah 3 bulan dapat dipanen kembali. Satu rumpun sereh wangi dapat menghasilkan 1,5 kg pada panen pertama dan meningkat menjadi 2,0 kg setelah panen berikutnya. Satu hektar lahan dapat memuat 1000-1500 rumpun sereh wangi. Minyak sereh wangi berharga $\mathrm{Rp} 250.000 / \mathrm{L}$, ampas sisa penyulingannya dapat dijadikan pakan ternak (Rp 150/kg) atau dijadikan trichokompos (Rp 1.200/kg). Trichokompos juga dibutuhkan untuk pupuk organik bagi kelangsungan budi daya sereh wangi. Integrasi budi daya dan industri pengolahan sereh wangi berdampak positif bagi upaya reklamasi lahan dan sekaligus pemberdayaan ekonomi masyarakat.
\end{abstract}

Kata kunci: bioreklamasi, minyak atsiri, sereh wangi, trichokompos

\begin{abstract}
Degraded land due to brick industry, piling material, and coal mining activities are widely covered the area of Kebon IX Village, Sungai Gelam Subdistrict, Muaro Jambi District. This service activity was aimed at encouraging collective action by the village community of Kebun IX to apply citronella cultivation and processing technology in order to rehabilitate their land as well as develop productive economic businesses as a substitute for their old businesses that were not environmentally friendly. The method used was the combination of Participatory Rural Appraisal (PRA) and collective action model in promotion strategy and technology adoption. Through counseling, training and demonstration plots, four types of integrated businesses, including cultivation, processing and utilization of citronella by-product, have been successfully developed in Kebon IX Village. Citronella plants at aged 6-8 months produced leaves at a price of IDR 500/kg and after 3 months can be harvested again. One clump of citronella plants can produce $1.5 \mathrm{~kg}$ at the first harvest and increase to $2.0 \mathrm{~kg}$ after the next harvest. One hectare of land can contain 1000-1500 clumps of citronella plants. Citronella plant soil costs IDR 250,000/L, the residue of the distillation can be used as animal feed (IDR 150/kg) or used as trichocompost (IDR 1,200/kg). Trichocompost is also needed as organic fertilizer for the continuity of citronella cultivation. The integration of citronella plants cultivation and processing industry has a positive impact on land reclamation efforts as well as to empower the community's economy.
\end{abstract}

Keywords: bioreclamation, citronella, essential oils, trichocompost 


\section{PENDAHULUAN}

Akumulasi degradasi sumber daya lahan di Desa Kebon IX, Kecamatan Sungai Gelam, Kabupaten Muaro Jambi akibat pemanfaatan yang tidak memerhatikan keseimbangan lingkungan berdampak terhadap kerugian ekologis dan juga kerugian sosial ekonomi. Lahan menjadi kritis dan kehilangan fungsi hidrologis akibatnya produktivitas lahan menjadi sangat rendah dan kesempatan memperoleh nilai manfaat ekonomi menjadi hilang.

Pada tahun 2016-2018, Universitas Jambi telah melaksanakan penelitian yang mengarustamakan prinsip-prinsip dasar pembangunan ekonomi hijau (green economic) dengan judul desain model pembelajaran 'green knowledge' berbasis 'green technology' pada lahan terdegradasi akibat aktivitas galian timbunan bandara dan industri batubata rakyat (Achmad et al. 2017). Penelitian ini sebagai upaya advokasi berbasis masyarakat untuk secara swadaya dan swakelola memulihkan dan memanfaatkan kembali lahan terdegradasi tersebut. Dampak penelitian ini di antaranya berupa peningkatan pengetahuan dan animo masyarakat untuk merehabilitasi lahan mereka. Dampak yang lainnya adalah terbentuknya 3 lembaga perekonomian masyarakat berupa usaha ekonomi produktif (UEP) dengan basis usaha pemanfaatan lahan kritis (SK Kepala Desa Kebon IX No. 25/KPTS/ 2017 tanggal 02 Agustus 2017).

Rekomendasi hasil penelitian tersebut adalah bahwa tanaman sereh wangi potensial untuk dijadikan agen bioreklamasi lahan, sesuai dengan pernyataan Litbang Pertanian (2012) bahwa sereh wangi memang bisa digunakan untuk keperluan konservasi lahan. Selain sebagai agen bioreklamasi, sereh wangi juga memiliki fungsi ekonomis yang baik bagi pengembangan beberapa UEP terkait (Achmad et al. 2017).

Pada pertengahan tahun 2018, teknologi budi daya sereh wangi di lahan masyarakat (di luar plot percontohan) telah mulai dilaksanakan, tidak kurang dari 4 ha lahan terdegradasi telah direklamasi dengan cara ditanami sereh wangi oleh kelompok UEP budi daya sereh wangi. Hasil panennya di awal tahun 2019 tidak kurang dari 40 ton, diperkirakan cukup untuk memenuhi kebutuhan bahan baku industri minyak atsiri (UEP penyulingan minyak sereh wangi). Kegiatan penyulingan minyak sereh wangi akan berimplikasi terhadap ketersediaan ampas sisa penyulingan. Ampas ini diketahui baik untuk digunakan sebagai pakan ternak sapi dan juga potensial untuk dijadikan bahan baku pembuatan trichokompos (kompos yang diperkaya dengan jamur trichoderma). Kegiatan ini akan menunjang keberlangsungan dua UEP lainnya, yaitu UEP penggemukan sapi dan UEP pengolahan trichokompos. Idealnya, keempat UEP ini akan saling terintegrasi dan saling menunjang untuk terus berkembang (Gambar 1).

Tiga bidang permasalahan yang menjadi kendala dan perlu diatasi demi keberlangsungan integrasi 4 UEP ini, adalah bidang produksi (penguasaan teknik budi daya dan pengolahan sereh wangi serta pemanfaatan hasil samping

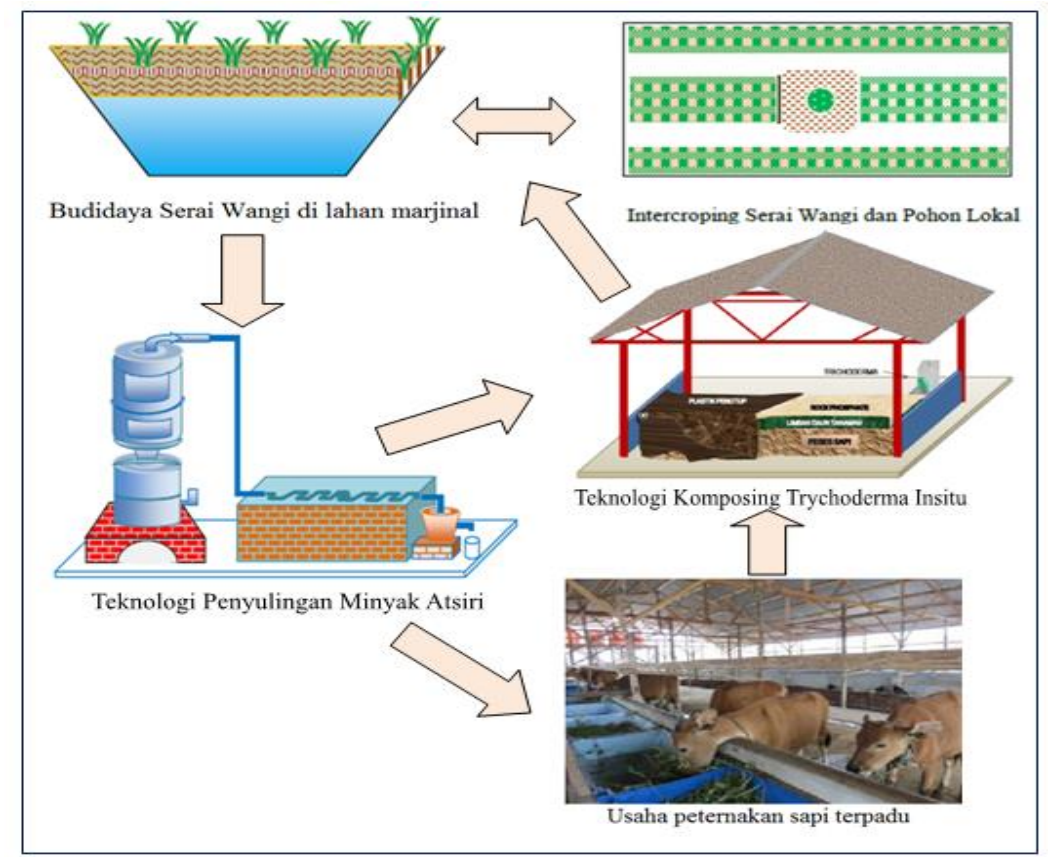

Gambar 1 Integrasi dan saling keterkaitan empat usaha ekonomi produktif yang ada di lokasi kegiatan. 
pengolahannya), bidang manajemen (ketidakmampuan manajemen, kurang pengalaman dalam mengelola suatu usaha, lemahnya kendali keuangan, dan ketidakmampuan membuat transisi kewirausahaan), dan bidang pemasaran (keterbatasan dalam menjangkau pasar). Pada tulisan ini pembahasan hanya dibatasi pada bidang produksi saja, bidang manajemen dan pemasaran akan dibahas dalam artikel yang lain.

Kegiatan pengabdian ini bertujuan untuk mendorong aksi kolektif masyarakat Desa Kebun IX untuk mengaplikasikan teknologi budi daya dan pengolahan sereh wangi dalam rangka merehabilitasi lahan mereka sekaligus mengembangkan UEP yang kelak dapat menjadi sumber pendapatan pengganti usaha lama mereka yang tidak ramah lingkungan (usaha tanah timbunan, industri batubata, dan penambangan batubara).

\section{METODE PELAKSANAAN KEGIATAN}

\section{Lokasi dan Partisipan Kegiatan}

Kegiatan ini dilaksanakan di Desa Kebun IX, Kecamatan Sungai Gelam, Kabupaten Muaro Jambi, Jambi. Mitra yang terlibat dalam kegiatan terdiri dari kelompok swadaya masyarakat Sukses Bersama; kelompok karang taruna Remaja Teladan Mandiri; dan kelompok UEP Budidaya Tanaman Sereh Wangi, Penyulingan Minyak Sereh Wangi, Penggemukan Sapi, dan Trichokompos.

\section{Aplikasi Teknologi Bioreklamasi}

Penyuluhan dilakukan sebanyak dua kali dalam rangka aplikasi teknologi bioreklamasi. Penyuluhan yang pertama dilakukan dengan tujuan untuk memberi motivasi kepada seluruh anggota kelompok UEP budidaya sereh wangi. Tema dari penyuluhan ini adalah "tanaman sereh wangi: agen bioreklamasi yang bernilai ekonomi tinggi". Penyuluhan kedua bertema "manfaat dan keuntungan finansial budi daya sereh wangi". Penyuluhan kedua ini dirangkaikan dengan kegiatan praktik budi daya tanaman sereh wangi di lahan marjinal milik salah satu anggota kelompok swadaya masyarakat Sukses Bersama.

Upaya melengkapi pengetahuan masyarakat tentang teknik budi daya sereh wangi, beberapa perwakilan kelompok dibawa berkunjung ke lokasi budi daya tanaman sereh wangi milik seorang warga Desa Sebapo, Kecamatan Mestong, Kabupaten Muaro Jambi (Pak Eko) yang telah mengusahakan lebih dari 5 ha tanaman sereh wangi selama lebih dari 5 tahun di berbagai lokasi.

Selama proses pemeliharaan tanaman, dilakukan kegiatan pendampingan secara intensif. Setiap masalah dan kendala pertumbuhan tanaman sereh wangi yang dihadapi oleh masyarakat selalu dicarikan jalan keluarnya. Praktik penyiangan dan pemupukan menggunakan pupuk kompos juga dilakukan untuk mengoptimalkan hasil budi daya. Teknik penanaman ini telah mengadopsi cara yang dianjurkan oleh Litbang Pertanian (2012) dan hasil penelitian Achmad et al. (2017).

Sereh wangi yang dibudidayakan berasal dari anakan. Anakan diperoleh dari Kebun Percobaan Balitro Laing, Solok, Sumatera Barat. Bibit sereh wangi berupa batang tunggal sepanjang $35 \mathrm{~cm}$ ditanam secara manual pada jarak $1 \times 1 \mathrm{~m}$ dengan cara membuat lubang tanam dalam larikan dengan ukuran $30 \times 30 \times 30 \mathrm{~cm}$. Setiap lubang tanam diisi dengan pupuk kandang hingga kedalaman lubang tinggal $10 \mathrm{~cm}$ di bawah permukaan larikan. Selama masa primodial jika tidak turun hujan dilakukan penyiraman minimal satu kali sehari. Setelah bibit tumbuh, dilakukan penyiangan rumput-rumput yang ikut tumbuh sebagai gulma.

\section{Penguatan Usaha Penyulingan Minyak Sereh Wangi}

Penguatan usaha penyulingan minyak sereh wangi dilakukan dengan cara meningkatkan kapasitas alat penyulingan sereh wangi dari 100 menjadi $550 \mathrm{~kg}$ daun sereh wangi karena telah dilakukan perluasan areal penanaman sereh wangi dari 1 ha menjadi 4 ha, maka peningkatan kapasitas alat suling ini menjadi urgen. Fakta lain yang ditemukan di lapangan bahwa masyarakat tidak hanya menanam sereh wangi pada areal tergedradasi tetapi sebagian dari mereka telah menanamnya di sekitar rumah atau di lahanlahan mereka yang tidak produktif. Produksi UEP budi daya sereh wangi ini dihargai $\mathrm{Rp} 500 / \mathrm{kg}$ daun basah oleh UEP penyulingan minyak sereh wangi.

Desain model alat penyulingan dikembangkan berdasarkan hasil rancangan dengan metode QFD (Bestari 2019), mempertimbangkan efisiensi, keamanan, dan kemudahan penggunaan. Rancangan alat penyulingan ini juga mengacu pada disain dan teknologi penyulingan minyak sereh wangi yang dikembangkan oleh beberapa peneliti akhir-akhir ini (Pertiwi et al. 2003; Feriyanto et al. 2013; Anwar et al. 2016; Achmad et al. 2018). Kegiatan perbaikan dan modifikasi 
serta peningkatan kapasitas alat penyulingan minyak sereh wangi ini memakan biaya sekitar 39 juta (diluar biaya tenaga kerja dan upah tukang karena dikerjakan secara gotong royong). Tim pengabdian memberikan bantuan berupa bak penampung air kondensat senilai Rp750.000, tungku distiller senilai Rp 4 juta, dan pipa penyalur uap panas dari tungku ke tangki penyuligan senilai Rp900.000. Transfer teknologi penyulingan minyak sereh wangi dilakukan dengan cara penyuluhan, pelatihan, dan pendampingan.

\section{Penguatan Usaha Penggemukan Sapi}

Hasil panen tanaman sereh wangi telah disuling dan menghasilkan produk samping berupa ampas penyulingan yang volumenya hampir sama banyak dengan hasil panen itu sendiri. Ampas penyulingan daun sereh wangi ini sebagiannya dimanfaatkan menjadi pakan ternak sapi untuk kelompok UEP penggemukan sapi dan para peternak yang ada di sekitar areal kegiatan.

Ternak diuji mengkonsumsi ampas penyulingan daun sereh wangi. Ampas yang diujikan kepada sapi adalah yang masih segar (tidak lebih dari 10 jam setelah diangkat dari tangki penyulingan). Respons ternak cukup positif, semua ampas dikonsumsi oleh sapi tanpa meninggalkan sisa. Ampas penyulingan ini sangat disukai ternak dan potensial digunakan sebagai substituen pakan hijauan sapi.

Ampas penyulingan minyak sereh wangi ini sebagai produk samping UEP penyulingan minyak sereh wangi, dihargai Rp 150/kg oleh UEP penggemukan sapi. Selanjutnya ampas ini dicampur dengan pakan hijauan berupa rumput dengan perbandingan ampas:rumput (30:70). Transfer teknologi pemanfaatan ampas penyulingan sereh wangi menjadi pakan ternak sapi dilakukan dengan cara penyuluhan, pelatihan, dan pendampingan.

\section{Penguatan UEP Trichokompos}

Selain digunakan untuk makanan ternak, ampas penyulingan daun sereh wangi sebagiannya dimanfaatkan menjadi bahan baku pembuatan trichokompos untuk kelompok UEP trichokompos. Setiap hari separoh dari ampas sisa penyulingan sereh wangi diolah menjadi trichokompos. Untuk luas areal budi daya 4 ha, maka dimasa panen setiap hari dapat dilakukan penyulingan minyak sereh wangi sebanyak 2 kali. Dengan demikian separoh dari ampas sisa penyulingan tersebut diperkirakan adalah $500 \mathrm{~kg}$ setiap harinya yang dapat digunakan sebagai bahan baku pembuatan trichokompos.

Pembuatan trichokompos mengacu pada cara yang dikembangkan oleh Asyerem (2011), bahan yang digunakan adalah pupuk kandang sebanyak $20 \mathrm{~kg}$, potongan ampas penyulingan minyak sereh wangi sebanyak $10 \mathrm{~kg}$, gula pasir sebanyak 0,5 kg, kapur pertanian sebanyak 0,25 kg, urea sebanyak $0,25 \mathrm{~kg}$, dan bibit tricho padat/cair sebanyak 250 gr/L. Cara pembuatannya adalah pupuk kandang dimasukkan kedalam bak fermentasi lalu ditambahkan potongan ampas penyulingan, urea, dan kapur pertanian. Setelah itu disiram air yang sudah dicampur gula dan trichoderma sampai kandungan air 60\%. Bisa juga bahan dicampur semuanya kemudian baru disiram dengan larutan gula dan trichokompos. Setelah itu bahan ditutup rapat dengan penutup dan difermentasi selama 21 hari, setiap 5 hari penutup dibuka dan kompos di bolak-balik kemudian ditutup lagi. sebaiknya pembuatannya menggunakan alas plastik dan di bawah naungan, diusahakan tidak terkena matahari langsung. Transfer teknologi pemanfaatan ampas penyulingan minyak sereh wangi menjadi trichokompos dilakukan dengan cara penyuluhan, pelatihan, dan pendampingan.

\section{HASIL DAN PEMBAHASAN}

\section{Budi Daya Sereh Wangi sebagai Aksi Bioreklamasi dan UEP}

Peningkatan pengetahuan masyarakat tentang budi daya sereh wangi ternyata dapat terwujud dengan adanya kegiatan penyuluhan, pelatihan, dan pendampingan. Animo masyarakat untuk ikut serta menanam sereh wangi cukup besar. Akhirnya bukan saja tanah terdegradasi yang dijadikan tempat budi daya sereh wangi, tetapi juga pekarangan dan lahanlahan tidak produktif lainnya yang ada di sekitar rumah warga.

Tanaman sereh wangi yang ditanam pada lahan kritis di lokasi pengabdian menunjukkan daya tahan hidup yang cukup baik. Diperlukan waktu rata-rata 7 hari untuk masing-masing bibit dapat tumbuh dan berkembang biak (menambah anakan). Secara rata-rata, tidak berbeda dengan hasil yang diperoleh di plot demonstrasi, sereh wangi dapat beradaptasi dengan baik di lahan terdegradasi di lokasi pengabdian. Pada lahan terdegradasi yang ditanami sereh wangi secara perlahan terlihat perbaikan fungsi lahannya 
menjadi lebih subur (Gambar 2). Setiap rumpun tanaman rata-rata menghasilkan berat daun segar di waktu panen pertamanya ( 6 bulan setelah tanam) sebesar $1,5 \mathrm{~kg}$.

Jika diasumsikan biaya olah tanah, penanaman, pemupukan, dan perawatan tanaman sebesar Rp 1.000/rumpun/tahun. Dengan kepadatan tanam 10.000 rumpun per hektar dan setiap rumpun menghasilkan daun sereh wangi sebanyak 1,5 kg setelah 6 bulan tanam dan $2 \mathrm{~kg}$ per rumpun setelah 3 bulan berikutnya dan dengan harga jual daun sereh wangi segar sebesar Rp 500/kg, maka penghasilan kelompok UEP ini dalam setahun pertama untuk setiap hektarnya adalah sebesar $\{(10.000 \times(1,5+2+$ 2) $) \times R p 500\}-\{(10.000 \times 400)+(10.000 \times 1.000)\}$ $=\mathrm{Rp}$ 13.500.000. Pada tahun kedua dan seterusnya (hingga tahun ke 20), penghasilan kelompok UEP ini akan menjadi sebesar $\{(10.000$ $\mathrm{x}(2+2+2+2) \times \mathrm{Rp} 500)-(10.000 \times 1.000)\}=\mathrm{Rp}$ 30.000 .000 per hektar.

Sebagai agen bioreklamasi, sereh wangi terbukti dapat memperbaiki fungsi lahan terdegradasi, dari lahan kritis berangsur menjadi lahan yang lebih subur. Secara ekonomi, budi daya sereh wangi juga dapat dijadikan usaha ekonomi produktif dengan marjin keuntungan yang cukup besar.

\section{Penguatan UEP Penyulingan Minyak Sereh Wangi}

Setelah kegiatan budi daya sereh wangi berhasil dikembangkan dengan baik, maka hal krusial lainnya yang juga perlu diintensifkan adalah mengoptimalkan penggunaan mesin penyuling minyak sereh wangi. Ketersediaan daun sereh wangi yang melimpah perlu diatasi dengan proses penyulingan yang lebih intensif dengan kapasitas yang lebih besar dan hasil yang lebih baik. Sebelumnya proses penyulingan minyak sereh wangi hanya dilakukan dengan alat suling dengan kapasitas 100-150 kg untuk setiap penyulingan. Kondisi alat penyuling juga masih sangat sederhana, hanya dengan memanfaatkan

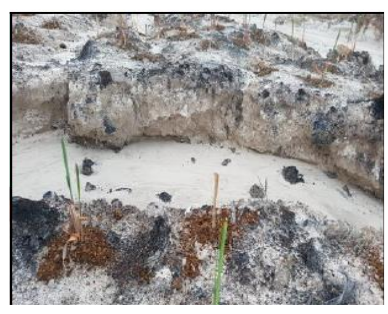

a

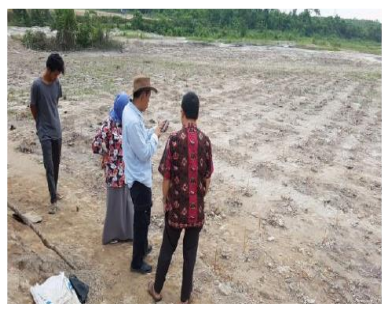

$\mathrm{b}$ drum bekas sebagai ketel tempat menempatkan daun sereh wangi yang akan disuling. Tempat penyulingan pun tidak beratap sehingga akan sangat mengganggu ketika terjadi hujan.

Transfer pengetahuan teknik penyulingan melalui kegiatan penyuluhan, pelatihan, dan pendampingan telah berhasil memotivasi masyarakat dan kelompok UEP penyulingan minyak sereh wangi berproduksi dengan lebih giat. Desain rumah penyulingan yang baru, berkapasitas $550 \mathrm{~kg}$ untuk setiap kali penyulingan dan dengan bangunan beratap yang semi permanen, kegiatan produksi minyak sereh wangi oleh kelompok UEP penyulingan minyak sereh wangi menjadi lebih efektif dan efisien. Dalam satu hari kegiatan penyulingan bisa dilakukan dua kali, tetapi saat ini baru dilakukan satu kali.

Kelompok UEP telah berinisiatif untuk melakukan pembelian daun sereh wangi dari petani di sekitar lokasi dan bahkan dari daerah Bayung Lencir dengan harga per kg Rp 500 (lima ratus rupiah). Dengan rendemen minyak 0,78\%, lama penyulingan 6 jam, menghabiskan bahan bakar oli bekas dan kayu bakar seharga Rp 120.000 , dari $550 \mathrm{~kg}$ daun sereh wangi kelompok UEP ini dapat menghasilkan minyak sereh wangi sebanyak 4,3 kg dengan harga jual $\mathrm{Rp}$ $250.000 / \mathrm{kg}$. Marjin keuntungan dari kegiatan menyuling ini sebesar Rp1.072.500 - 275.000 $120.000=\operatorname{Rp} 677.000$.

\section{Penguatan UEP Penggemukan Sapi}

Jika separoh dari ampas sisa penyulingan minyak sereh dimanfaatkan sebagai pakan hijauan ternak sapi, berarti setiap bulannya tidak kurang dari 12 ton ampas sisa penyulingan minyak sereh wangi tersedia sebagai bahan pakan ternak sapi. Hijauan ini akan sangat bermanfaat untuk usaha penggemukan sapi.

Hasil pengamatan selama ini, sapi yang ada di kandang di Desa Kebun IX Kecamatan Sungai Gelam tidak menolak untuk mengkonsumsi ampas sisa penyulingan minyak sereh wangi
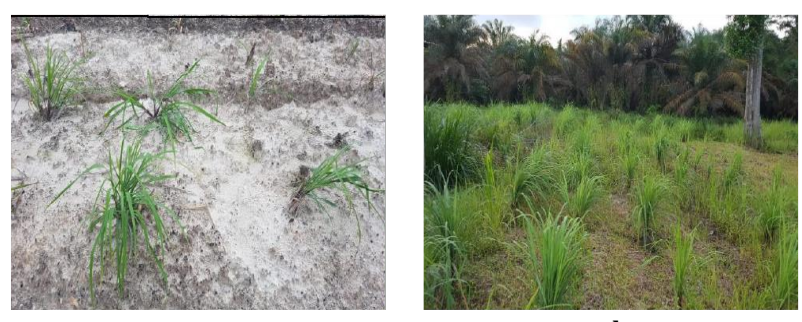

d

Gambar 2 Teknologi bioreklamasi lahan di Desa Kebun IX Kecamatan Sungai Gelam, a dan b) Lahan yang terdegradasi, serta $\mathrm{c}$ dan d) Lahan yang sudah ditanami sereh wangi. 
yang dicampur dengan rumput yang biasa dimakannya. Penelitian tentang hubungan antara substitusi pakan hijauan sapi dengan ampas penyulingan minyak sereh wangi membuktikan bahwa pertambahan bobot badan pada induk sapi yang hanya diberi rumput gajah ditambah konsentrat adalah sebesar $0,26 \mathrm{~kg} /$ ekor/hari, tidak berbeda nyata $(\mathrm{P}>0,05)$ dengan pertambahan bobot induk sapi yang diberi rumput gajah $80 \%$, limbah sereh wangi hasil penyulingan $20 \%$ ditambah konsentrat, yaitu sebesar 0,24 kg/ekor/hari (Nurhayu \& Warda 2018). Perbandingan kandungan gizi limbah sereh wangi dengan rumput gajah disajikan pada Tabel 1.

\section{Penguatan UEP Trichokompos}

Jika setengah dari ampas penyulingan minyak sereh wangi telah dimanfaatkan untuk pakan ternak, maka sisanya (tidak kurang dari 12 ton/bulan) potensial digunakan sebagai bahan baku pembuatan trichokompos. Biaya produksi untuk menghasilkan $1 \mathrm{~kg}$ trichokompos diperlukan sekitar Rp 835; harga jual trichokompos per kg dibandrol Rp 1.200. Nilai R/C usaha ini sebesar 1,62 berarti prospek pengembangan usaha ini sangat baik, untuk setiap kali produksi akan dihasilkan keuntungan sebesar 1,62 kali biaya yang dikeluarkan. Analisis biaya pembuatan trichokompos dapat dilihat pada Tabel 2.

\section{SIMPULAN}

Integrasi budi daya dan industri pengolahan sereh wangi berdampak positif bagi upaya reklamasi lahan dan sekaligus pemberdayaan ekonomi masyarakat desa. Empat UEP yang telah diupayakan pengembangannya saat ini (budi daya sereh wangi, penyulingan minyak sereh wangi, pembuatan trichokompos, dan penggemukan sapi) merupakan model UEP yang sangat potensial dikembangkan.

Tabel 1 Perbandingan kandungan gizi ampas penyulingan sereh wangi, rumput gajah, dan jerami padi

\begin{tabular}{lrrr}
\hline \multicolumn{1}{c}{ Parameter gizi } & Ampas sereh wangi & Rumput gajah & Jerami padi \\
\hline Protein & 7,00 & 10,19 & 3,93 \\
Lemak & 2,35 & 1,64 & 0,87 \\
Energi (kkg/Ge/kg) & 3353,00 & 4031,00 & 3167,00 \\
Serat kasar (\%) & 25,73 & 34,15 & 32,99 \\
Ca (\%) & 0,35 & 0,48 & 1,20 \\
P (\%) & 0,14 & 0,23 & 1,20 \\
Kadar abu (\%) & 7,91 & 11,73 & 22,44 \\
\hline
\end{tabular}

Sumber: Sukamto et al. (2011).

Tabel 2 Analisis ekonomi pembuatan trichokompos dari bahan baku ampas penyulingan minyak sereh wangi dan kotoran sapi

\begin{tabular}{lrrrr}
\hline Uraian & Jumlah & Satuan & Harga/satuan (Rp) & Jumlah harga (Rp) \\
\hline Biaya & & & & \\
Trichoderma & 40 & $\mathrm{~L}$ & 25.000 & 1.000 .000 \\
Kotoran Sapi & 24.000 & $\mathrm{~kg}$ & 200 & 4.800 .000 \\
Kapur Pertanian & 600 & $\mathrm{~kg}$ & 3.000 & 1.800 .000 \\
Urea & 600 & $\mathrm{~kg}$ & 3.000 & 1.800 .000 \\
Gula Pasir & 300 & $\mathrm{~kg}$ & 12.000 & 3.600 .000 \\
Ampas Sereh Wangi & 12.000 & $\mathrm{~kg}$ & 150 & 1.800 .000 \\
Tenaga kerja & 8 & $\mathrm{OB}$ & 100.000 & 800.000 \\
Penyusutan saung & 1 & $\mathrm{bulan}$ & & 400.000 \\
Total Biaya & & & & 16.000 .000 \\
\hline Produk (60\% x 36,000 kg) & 21.600 & $\mathrm{~kg}$ & & \\
Biaya produksi/kg (16 jt/21.600) & 740,74 & $\mathrm{Rp}$ & & \\
Harga jual/kg & 1.200 & $\mathrm{Rp}$ & & \\
Nilai Penjualan (21,600 x 1,200) & 25.920 .000 & $\mathrm{Rp}$ & & \\
Keuntungan per bulan & 9.920 .000 & $\mathrm{Rp}$ & & \\
R/C & 1,62 & & & \\
\hline
\end{tabular}




\section{UCAPAN TERIMA KASIH}

Ucapan terima kasih kami sampaikan kepada DRPM Kemenristekdikti yang telah memberikan dana bagi keberlangsungan kegiatan pengabdian kepada masyarakat ini dalam skema Program Kemitraan Masyarakat tahun 2019. Ucapan terima kasih juga kami sampaikan kepada semua pihak yang telah berpartisipasi aktif dalam kegiatan pengabdian ini.

\section{DAFTAR PUSTAKA}

Achmad E, Mursalin, Novra A. 2017. Desain model pembelajaran "green knowledge" berbasis "green technology" pada lahan terdegradasi akibat aktivitas galian timbunan bandara dan industri batubata rakyat. [Laporan Penelitian]. DP2M Kemenristek DIKTI.

Achmad E, Mursalin, Novra A. 2018. Rendemen minyak sereh wangi (Cymbopogon nardus L) yang dibudidayakan di lahan terdegradasi akibat aktivitas galian timbunan bandara. Dalam: Prosiding Seminar Nasional Teknopreneur Universitas Pasir Pengaraian. 1(1): 143-150. Riau (ID), Rokan Hulu, 31 Juli 2018.

jksp.v1i1.343

Anwar A, Nugraha, Nasution A, Amaranti R. 2016. Teknologi penyulingan minyak sereh wangi skala kecil dan menengah di Jawa Barat. Teknoin. 22(9): 664-672. https://doi.org/ 10.20885/teknoin.vol22.iss9.art4

Asyerem FSJ. 2011. Pemanfaatan agen hayati trichoderma spp dan bakteri selulotik untuk pengomposan Ageratum conyzoi-desvar Hirtum (Lam), Tithonia diversifolia (Hamsley) A. Gray dan ampas sagu sebagai pupuk organik pada cabai merah (Capsicum
AnnuumL.). [Tesis]. Bogor (ID): Institut Pertanian Bogor.

Bestari RT. 2019. Rancangan alat penyuling minyak atsiri berdasarkan kriteria quality function deployment (QFD) dan House of quality (HOQ). [Skripsi]. Jambi (ID): Universitas Jambi.

Feriyanto YE, Sipahutar PJ, Mahfud, Prihatini P. 2013. Pengambilan minyak atsiri dari daun dan batang serai wangi (Cymbopogon winterianus) menggunakan metode distilasi uap dan air dengan pemanasan microwave. Pomits. 2(1): 93-97.

Litbang Pertanian. 2012. Tanaman Atsiri untuk Konservasi dan Sumber Pendapatan Petani. [Internet]. [diunduh 20 Mei 2017]; tersedia pada:

http://www.litbang.pertanian.go.id/artikel/o ne/154/pdf/Tanaman\%20Atsiri\%20untuk\% 20Konservasi\%20dan\%20Sumber\%20Penda patan\%20Petani.pdf.

Nurhayu A, Warda. 2018. Pengaruh pemberian limbah sereh wangi hasil penyulingan minyak atsiri sebagai pakan ternak terhadap penampilan induk sapi bali. Biocelebes. 12(3): $30-40$.

Pertiwi DS, Gunawan A, Avicenna JM. 2003. Peningkatan kualitas minyak sereh wangi dengan distilasi kukus. Dalam: Prosiding Seminar Nasional Teknologi Proses Kimia V UI Jakarta. Jakarta (ID), 26 Maret 2003.

Sukamto, Djazuli M, Suheryadi D. 2011. Seraiwangi (Cymbopogon nardus L) sebagai penghasil minyak atsiri, tanaman konservasi dan pakan ternak: Inovasi Teknologi Mendukung Peningkatan Nilai Tambah, Daya Saing dan Ekspor Perkebunan. Dalam: Prosiding Seminar Nasional Inovasi Perkebunan. Bogor (ID): Puslitbangbun. hlm. 175-180. 